\title{
Pemberian Bubur Formula Protein Hidrolisat dan Bubur Soya dalam Pencegahan Alergi Susu Sapi
}

\author{
Zakiudin Munasir, Sjawitri P Siregar, Sri S Nasar, Nia Kurniati
}

Latar belakang. Alergi susu sapi (ASS) sering merupakan penyakit alergi pertama pada seorang bayi. Upaya pencegahan terhadap alergi protein susu sapi berupa pencegahan primer, sekunder atau tersier.

Tujuan. Untuk membandingkan bubur yang mengandung protein susu sapi hidrolisis parsial dengan bubur yang mengandung isolat protein soya sebagai makanan pendamping pada bayi berisiko alergi tinggi terjadinya ASS.

Metoda. Penelitian uji klinik acak buta ganda ini dilakukan pada bayi usia 4-6 bulan yang mempunyai bakat atopik dengan pemberian dua jenis bubur yaitu bubur hipoalergenik dan bubur soya.

Hasil. Didapatkan 84 bayi yang dapat dievaluasi sampai akhir penelitian, terdiri dari 47 (56\%) bayi laki-laki dan 37 (44\%) bayi perempuan. Subyek dibagi menjadi kelompok bubur hipoalergenik (HA) 47 bayi (56\%) dan kelompok bubur bubur soya 37 bayi (44\%). Sebagian besar evaluasi skor gejala alergi menunjukkan hasil skor yang tidak timbul atau skor yang menurun, yaitu masing-masing 39 bayi (46,4\%) dan 36 bayi $(42,9 \%)$. Pengukuran kadar IgE spesifik protein susu sapi pada awal dan akhir penelitian sebagian besar menunjukkan hasil negatif, yaitu masing-masing 62 bayi $(86,1 \%)$ dan 43 bayi $(70,5 \%)$. Tidak ada hubungan yang bermakna antara evaluasi skor gejala alergi antara kedua kelompok bubur, ataupun antara kadar IgE spesifik protein susu sapi pada akhir penelitian pada kedua kelompok bubur yang hanya menggunakan susu hipoalergenik atau ASI.

Kesimpulan. Bubur protein soya yang dikombinasi dengan susu hipoalergenik atau ASI mempunyai manfaat yang sama dengan bubur hipoalergenik dalam mencegah timbulnya ASS. Kedua kelompok bubur juga dapat menghasilkan kenaikan berat badan dan panjang badan yang sama.

Kata kunci: alergi susu sapi, bubur hipoalergenik, pencegahan alergi

Alamat korespondensi:

Dr. Zakiudin Munasir, Sp.A(K)

Divisi Alergi Imunologi. Departemen Ilmu Kesehatan Anak FKUI-

RSCM Jl. Salemba no. 6, Jakarta 10430

Telepon: 021-3161144. Fax: 021-3907743

E-mail : sulastri@indosat.net.id
C enyakit alergi pada bayi paling sering dicetuskan oleh alergen makanan. Seringkali manifestasi alergi makanan berhubungan dengan urutan makanan yang dikenalkan sesuai umurnya. Alergen penting yang banyak dilaporkan pada tahun pertama kehidupan adalah susu sapi, buahbuahan dan sayuran. ${ }^{1-4}$ Susu sapi adalah bahan dasar susu formula bayi yang mengandung protein kasein, $\hat{\mathrm{a}}$ - 
laktoglobulin, dan a-laktalbumin dan pada sebagian orang merupakan protein asing yang dapat menimbulkan alergi. Protein susu sapi adalah protein asing utama yang pertama diberikan kepada seorang bayi.

Alergi susu sapi (ASS) sering merupakan penyakit alergi pertama pada seorang bayi. Alergi susu sapi adalah kelainan yang didasari suatu reaksi imunologis yang dapat dibuktikan dengan uji eliminasi provokasi. Reaksi alergi ini harus dapat dibedakan dengan reaksi intoleransi makanan yang bukan berdasarkan kelainan imunologis seperti efek toksik dari stafilokokus, defek metabolik akibat kekurangan enzim laktase, dan reaksi idiosinkrasi. ${ }^{5}$

Insidens ASS 2\%-3\% di antara keseluruhan bayi, ${ }^{6}$ sedangkan di antara bayi umur 1 tahun dengan dermatitis atopik 30-45\% disebabkan ASS. Di samping gejala pada kulit, ASS dapat menunjukkan gejala saluran napas dan saluran cerna tipe segera bahkan gejala sistemik berupa reaksi anafilaksis. Diperkirakan ASS dapat juga memberikan gejala reaksi tipe lambat yang timbul setelah 24 jam berupa sindrom kolik pada usia bayi (infantile colic syndrome).,78

Tata laksana alergi susu sapi meliputi penghindaran susu formula atau makanan yang mengandung protein susu sapi. Susu formula yang digunakan adalah yang mengandung protein hidrolisat sempurna. Protein soya dapat digunakan sebagai susu formula pada bayi alergi protein susu sapi meski terdapat 10\%-15\% kasus alergi protein susu sapi yang juga memiliki IgE terhadap soya. ${ }^{9}$ Angka kejadian hipersensitifitas pada soya dilaporkan rendah di negara Asia, namun soya yang dikonsumsi dengan cara pengolahan yang berbeda dengan negara maju. ${ }^{10}$

Upaya pencegahan terhadap alergi protein susu sapi telah banyak dilakukan di berbagai negara maju. Pencegahan ini berupa pencegahan primer, sekunder atau tersier. Rekomendasi pencegahan primer cukup bermakna dilakukan pada bayi baru lahir yang memiliki risiko tinggi alergi yaitu ibu memiliki riwayat atopi atau saudara kandung dengan riwayat penyakit alergi yang jelas dan/atau terbukti dengan pemeriksaan IgE total tali pusat yang tinggi. Pada bayi dari kelompok risiko tinggi ini dianjurkan pemberian ASI eksklusif selama minimal 4 bulan, atau memberikan susu formula hipoalergenik yang dihidrolisis parsial sejak lahir, atau menunda pemberian makanan padat hingga usia 6 bulan. ${ }^{11}$

Pada saat makanan padat diperkenalkan, proses sensitisasi atau terjadinya alergi susu sapi masih dapat terjadi sampai usia 2 atau 3 tahun. Oleh karena itu bayi dengan risiko atopi dianjurkan untuk menunda pemberian makanan yang hiperalergenik seperti susu sapi, telur, kacang tanah, makanan laut dan coklat hingga umur di atas 1 tahun. Toleransi terhadap protein susu sapi dapat terjadi pada usia sedini-dininya 2 tahun, terutama pada yang dasar imunologiknya bukan diperantarai $\operatorname{IgE}$.

\section{Tujuan Penelitian}

Penelitian bertujuan mengetahui efikasi 2 produk bubur bayi, yaitu bubur yang mengandung protein hidrolisat parsial (selanjutnya disebut bubur formula hidrolisat) dan bubur isolat protein soya yang diperkirakan dapat mencegah alergi pada bayi yang mempunyai bakat atopik (pencegahan primer dan sekunder). Selain itu, penelitian juga bertujuan untuk mengetahui akseptabilitas serta toleransi pemberian kedua bubur tersebut.

\section{Metoda}

Desain penelitian adalah uji klinik acak buta ganda dengan subyek penelitian (1) bayi usia 4-6 bulan yang mempunyai bakat atopik (riwayat alergi pada ayah, ibu atau saudara kandung), (2) bayi dengan kadar IgE spesifik protein susu sapi yang negatif dengan atau tanpa gejala alergi yang bukan disebabkan oleh susu sapi atau (3) bayi dengan kadar IgE spesifik protein susu sapi yang positif tanpa adanya gejala alergi dan sejak lahir mendapat ASI ekslusif atau susu hipoalergenik hidrolisis parsial. Bayi yang sudah pernah mendapat formula susu sapi atau bubur susu sapi regular atau sudah menunjukkan gejala alergi yang disebabkan oleh susu sapi tidak disertakan dalam penelitian. Subyek penelitian adalah pasien yang berobat di poliklinik Ilmu Kesehatan Anak RS Dr. Cipto Mangunkusumo Jakarta serta dari praktek pribadi dokter spesialis anak.

Subyek mendapat bubur formula hidrolisat atau bubur protein soya secara alokasi acak, setelah dilakukan anamnesis, pemeriksaan fisik dan pemeriksaan laboratorium. Tiap subyek diperiksa darah perifer lengkap, kadar eosinofil dan IgE spesifik protein susu sapi. Subyek dipantau tiap bulan selama 6 bulan 
Tabel 1. Panduan sistem skor

\begin{tabular}{|c|c|}
\hline Sistem & Skor \\
\hline \multicolumn{2}{|l|}{ Kulit } \\
\hline \multirow{3}{*}{ Eksim/gatal } & $0=$ tidak ada kelainan \\
\hline & $1=$ hanya di tubuh ATAU tungkai \\
\hline & $2=$ di tubuh DAN tungkai bila ada gatal, skor ditambah 1 \\
\hline \multirow[t]{3}{*}{ Urtikaria } & $0=$ tidak ada urtikaria atau rash \\
\hline & $1=$ kurang dari 10 lesi, tidak konfluens \\
\hline & 2 = lebih dari 10 lesi dan atau konfluens \\
\hline \multirow[t]{3}{*}{ (Angio)edema } & $0=$ tidak ada edema \\
\hline & $1=($ angio $)$ edema ringan \\
\hline & $2=($ angio $)$ edema berat dengan gejala sekunder seperti stridor \\
\hline \multicolumn{2}{|r|}{ 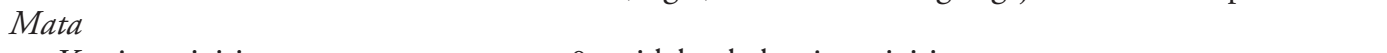 } \\
\hline \multirow{3}{*}{ Konjungtivitis } & $0=$ tidak ada konjungtivitis \\
\hline & $1=$ konjungtivitis hanya merah \\
\hline & $2=$ konjungtivitis merah dan bengkak \\
\hline \multicolumn{2}{|l|}{ Saluran nafas } \\
\hline \multirow[t]{4}{*}{ Sesak/batuk/mengi } & $0=$ tidak ada gejala \\
\hline & $1=$ hanya satu gejala \\
\hline & $2=$ ada dua gejala \\
\hline & 3 = ketiga gejala ada \\
\hline \multirow[t]{2}{*}{ Hidung tersumbat/hipersekresi } & $0=$ tidak ada gejala \\
\hline & $1=$ hidung tersumbat $/$ hipersekresi \\
\hline \multirow[t]{2}{*}{ Bersin } & $0=$ tidak ada bersin \\
\hline & $1=$ bersin-bersin \\
\hline \multirow[t]{3}{*}{ Hasil auskultasi } & $0=$ tidak ada kelainan \\
\hline & $1=$ hanya mengi ATAU ronki \\
\hline & $2=$ mengi ATAU ronki \\
\hline \multicolumn{2}{|l|}{ Saluran cerna } \\
\hline \multirow[t]{2}{*}{ Diare } & $0=$ tidak ada diare \\
\hline & $\begin{array}{l}1=\text { feses lunak, defekasi lebih sering dari normal } \\
2=\text { feses encer atau kehijauan }\end{array}$ \\
\hline \multirow[t]{2}{*}{ Obstipasi } & $0=$ tidak ada obstipasi \\
\hline & 1 = ada obstipasi \\
\hline \multirow[t]{2}{*}{ Anoreksia } & $0=$ tidak ada anoreksia \\
\hline & $1=$ ada anoreksia \\
\hline \multirow[t]{2}{*}{ Muntah } & $0=$ tidak ada muntah \\
\hline & $1=$ ada muntah \\
\hline \multirow[t]{3}{*}{ Kolik abdominal } & $0=$ tidak ada kolik \\
\hline & $1=$ kolik dengan menangis kurang dari 3 jam $/$ hari \\
\hline & $2=$ kolik dengan menangis lebih dari $3 \mathrm{jam} / \mathrm{hari}$ \\
\hline \multicolumn{2}{|r|}{ 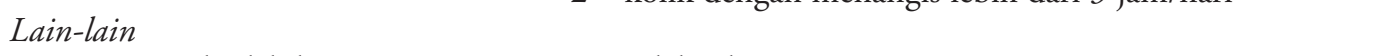 } \\
\hline \multirow[t]{2}{*}{ Menangis berlebihan } & $0=$ tidak ada \\
\hline & $1=$ menangis berlebihan \\
\hline \multirow[t]{3}{*}{ Gejala mulut } & $0=$ tidak ada gejala \\
\hline & $1=$ mulut gatal atau bengkak \\
\hline & $2=$ kedua gejala di atas, disertai stomatitis \\
\hline
\end{tabular}

bersama dengan laporan harian masukan makanan dan gejala alergi yang timbul pada kulit, mata, saluran nafas, saluran cerna dan gejala lainnya melalui penilaian skor untuk masing-masing sistem (Tabel 1). Dari skor masing-masing sistem didapatkan skor total. Pada akhir penelitian dilakukan penilaian ulang termasuk pemeriksaan darah perifer lengkap dan IgE spesifik protein susu sapi. 


\section{Hasil dan Diskusi}

Didapatkan subyek penelitian 106 orang bayi; 84 bayi diantaranya dapat dievaluasi sampai akhir penelitian, terdiri dari 47 (56\%) laki-laki dan 37 (44\%) bayi perempuan. Subyek dibagi menjadi 2 kelompok bubur, yaitu kelompok bubur formula hidrolisat atau bubur hipoalergenik (HA) 47 bayi (56\%) dan kelompok bubur protein soya atau bubur soya 37 bayi (44\%) (Tabel 2)

Selama penelitian dilakukan pemantauan terhadap gejala alergi yang timbul pada kulit, mata,

Tabel 2. Karakteristik data

\begin{tabular}{lcc}
\hline Variabel $(\mathbf{n}=\mathbf{8 4})$ & Frekuensi & $\%$ \\
\hline Jenis bubur & & \\
$\quad$ HA (hipoalergenik) & 47 & 56 \\
$\quad$ Soya & 37 & 44 \\
Jenis kelamin & & \\
$\quad$ Laki-laki & 47 & 56 \\
$\quad$ Perempuan & 37 & 44 \\
Skor alergi kunjungan pertama $(\mathrm{n}=84)$ & & \\
$\quad$ Skor 0 & 42 & 50 \\
$\quad$ Skor 1 & 24 & 28,6 \\
$\quad$ Skor 2 & 16 & 19 \\
$\quad$ Skor 3 & 2 & 2,4 \\
Evaluasi skor & & \\
$\quad$ Naik & 6 & 7,1 \\
$\quad$ Tetap & 3 & 3,6 \\
$\quad$ Turun & 36 & 42,9 \\
$\quad$ Tidak timbul & 39 & 46,4 \\
\hline
\end{tabular}

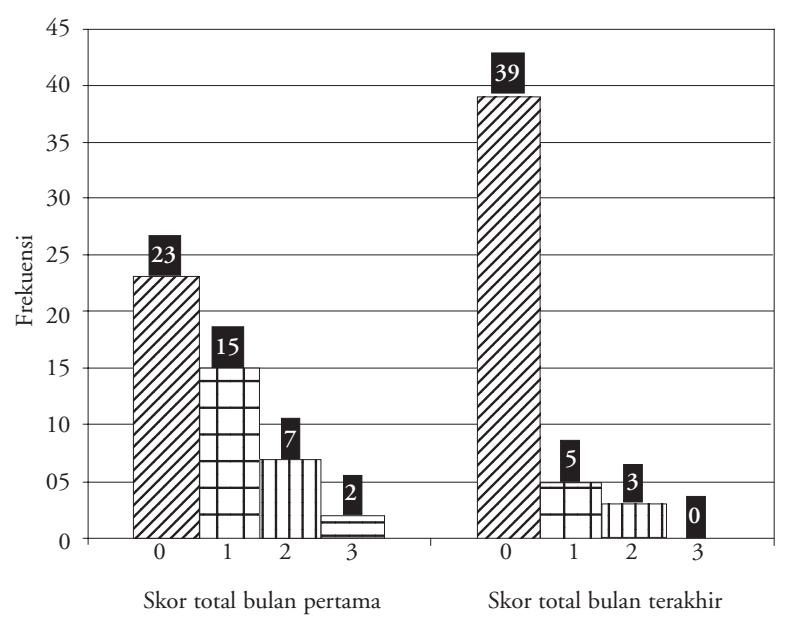

Gambar 1. Perubahan nilai total skor gejala alergi pada kelompok bubur hipoalergenik saluran nafas, saluran cerna dan gejala lainnya dengan menggunakan sistem skor. Nilai total skor 0 menunjukkan tidak ada gejala alergi, sedangkan nilai total skor di atas 0 menunjukkan adanya gejala alergi. Pada kunjungan pertama, 42 bayi (50\%) mempunyai nilai total skor $0 ; 24$ bayi $(28,6 \%)$ mempunyai nilai total skor $1 ; 16$ bayi (19\%) mempunyai nilai total skor 2 ; dan 2 bayi $(2,4 \%)$ mempunyai nilai total skor 3 (Tabel 2). Nilai total skor 0 juga memiliki persentase terbesar pada kedua kelompok bubur, yaitu 23 bayi $(48,9 \%)$ pada kelompok bubur HA dan 19 bayi $(51,4 \%)$ pada kelompok bubur soya (Gambar 1 dan 2). Pada akhir penelitian, nilai total skor 0 semakin bertambah, yang menandakan semakin banyak bayi yang tidak menunjukkan gejala alergi.

Pada skor total bulan terakhir pada bubur hipoalergenik, terjadi perubahan skor total :

1. Skor total 0 menjadi 39 bayi, terdiri dari :

- Skor 0 (tetap) : 22 bayi

- Berubah dari skor 1:11 bayi

- Berubah dari skor 2: 4 bayi

- Berubah dari skor 3:2 bayi

2. Skor total 1 menjadi 5 bayi, terdiri dari :

- Skor 1 (tetap) : 2 bayi

- Berubah dari skor 0:1 bayi

- Berubah dari skor 2: 2 bayi

3. Skor total 2 menjadi 3 bayi, terdiri dari :

- $\quad$ Skor 2 (tetap) : 1 bayi

- Berubah dari skor $1: 2$ bayi

4. Skor total 3 menjadi 0 bayi

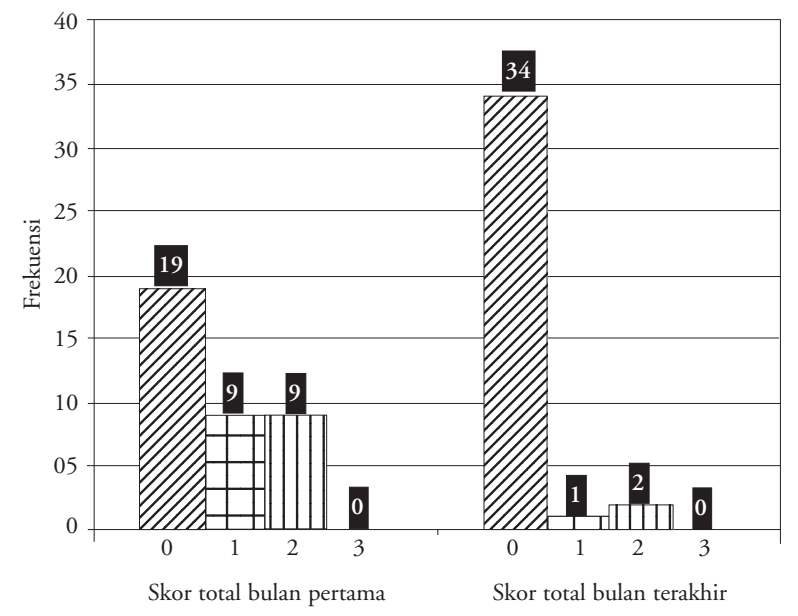

Gambar 2. Perubahan nilai total skor gejala alergi pada kelompok bubur soya 
Pada skor total bulan terakhir pada bubur soya, terjadi perubahan skor total :

1. Skor total 0 menjadi 34 bayi, terdiri dari :

- $\quad$ Skor 0 (tetap) : 17 bayi

- Berubah dari skor 1:8 bayi

- Berubah dari skor 2:9 bayi

2. Skor total 1 menjadi 1 bayi, terdiri dari :

- Berubah dari skor $0: 1$ bayi

3. Skor total 2 menjadi 2 bayi, terdiri dari :

- Berubah dari skor $0: 1$ bayi

- Berubah dari skor 1: 1 bayi

Perubahan nilai total skor sesuai dengan pemantauan evaluasi skor sampai akhir penelitian terhadap 84 bayi. Sebagian besar menunjukkan hasil skor yang tidak timbul atau menunjukkan hasil skor yang menurun, yaitu masing-masing sebanyak 39 bayi $(46,4 \%)$ dan 36 bayi $(42,9 \%)$ berarti sebagian besar bayi menunjukkan penurunan gejala alergi atau sama sekali tidak timbul gejala alergi. Sedangkan sisanya 6 bayi $(7,2 \%)$ menunjukkan skor yang naik dan 3 bayi $(3,6 \%)$ dengan skor alergi yang tetap, artinya tidak ada perubahan pada gejala alergi atau bahkan mengalami peningkatan gejala alergi (Tabel 2). Gambaran skor secara umum tersebut tidak berbeda dengan gambaran skor pada kedua kelompok bubur. Pada kelompok bubur HA didapatkan evaluasi skor yang turun atau tidak timbul mempunyai persentase yang tidak jauh berbeda, yaitu masing-masing $19(40,4 \%)$ dan 22 bayi (46,8\%). Sedangkan sisanya 3 bayi $(6,4 \%)$ menunjukkan skor yang naik dan 3 bayi lainnya $(6,4 \%)$ menunjukkan skor tetap. Demikian pula pada kelompok bubur soya, skor alergi yang turun terdapat pada 17 bayi $(45,9 \%)$, skor alergi tidak timbul pada 17 bayi $(45,9 \%)$, sedangkan 3 bayi sisanya $(8,1 \%)$ menunjukkan skor alergi yang naik.

Pengukuran kadar IgE spesifik protein susu sapi pada awal penelitian berhasil dilakukan pada 72 bayi (Tabel $3)$, dengan sebagian besar menunjukkan hasil negatif, yaitu 62 bayi $(86,1 \%)$, yang terdiri dari 31 bayi $(83,8 \%)$ pada kelompok bubur HA dan 31 bayi $(88,6 \%)$ pada kelompok bubur soya. Sebanyak 10 bayi (13,9\%) mempunyai hasil pemeriksaan $\mathrm{IgE}$ spesifik protein susu sapi awal yang positif, terdiri dari 6 bayi $(16,2 \%)$ pada kelompok bubur HA dan 4 bayi $(11,4 \%)$ pada kelompok bubur soya. Pengukuran kadar IgE spesifik protein susu sapi pada akhir penelitian berhasil dilakukan pada 61 bayi (Tabel 3), dengan hasil negatif sebanyak 43 bayi (70,5\%), yang terdiri dari 27 bayi $(79,4 \%)$ pada kelompok bubur HA dan 16 bayi $(59,3 \%)$ pada kelompok bubur soya. Sebanyak 18 bayi (29,5\%) mempunyai hasil pemeriksaan $\mathrm{IgE}$ spesifik protein susu sapi akhir yang positif, terdiri dari 7 bayi (20,6\%) pada kelompok bubur HA dan 11 bayi (40,7\%) pada kelompok bubur soya. Pengukuran kadar eosinofil juga dilakukan pada awal dan akhir penelitian. Kedua pengukuran menunjukkan sebagian besar hasil pemeriksaan dalam batas normal, masingmasing 87,5\% dan 96,6\% (Tabel 3).

Adanya gejala alergi yang ditampilkan melalui evaluasi skor tidak mempunyai hubungan yang bermakna pada kedua kelompok bubur $(\mathrm{p}=0,725)$ (Tabel 4).

Hal tersebut menunjukkan bahwa bubur hipoalergenik maupun bubur protein soya dapat dijadikan pilihan sebagai makanan padat pada bayi dalam rangka mencegah atau menghindari gejala alergi susu sapi. Bubur hipoalergenik dapat dijadikan profilaksis dalam mencegah alergi karena masih mengandung protein susu sapi yang terhidrolisat parsial yang dapat merangsang timbulnya toleransi terhadap susu sapi di kemudian hari. Sedangkan bubur protein soya dapat dijadikan profilaksis dalam mencegah alergi walaupun tidak mengandung protein susu sapi, tetapi susu yang dikonsumsi adalah ASI atau susu hipoalergenik yang mengandung protein susu sapi yang terhidrolisat parsial. Dari 37 bayi yang berada pada kelompok bubur soya, 17 bayi $(45,9 \%)$ di antaranya menggunakan susu hipoalergenik dan 6 bayi $(16,2 \%)$ mendapat ASI. Hasil ini ditunjang oleh hasil uji statistik yang mencari hubungan antara kadar IgE spesifik protein

Tabel 3. Hasil pemeriksaan IgE susu sapi dan eosinofil pada awal dan akhir penelitian

\begin{tabular}{lcc}
\hline \multirow{2}{*}{ Klasifikasi interpretasi } & \multicolumn{2}{c}{ Pemeriksaan IgE/n(\%) } \\
\cline { 2 - 3 } & Awal $(\mathbf{n}=72)$ & Akhir $(\mathbf{n}=\mathbf{6 1})$ \\
\hline Negatif & $62(86,1)$ & $43(70,5)$ \\
Positif : Rendah & $6(8,3)$ & $9(14,8)$ \\
\multicolumn{1}{c}{ Sedang } & $4(5,6)$ & $8(13,1)$ \\
\multicolumn{1}{c}{ Tinggi } & $0(0)$ & $1(1,6)$ \\
Eosinofil & & \\
Normal & $(\mathrm{n}=72)$ & $(\mathrm{n}=59)$ \\
Tinggi & $63(87,5)$ & $57(96,6)$ \\
\hline
\end{tabular}

Tabel 4. Penilaian evaluasi skor pada kedua jenis bubur

\begin{tabular}{lccc}
\hline \multirow{2}{*}{ Evaluasi skor } & \multicolumn{2}{c}{ Jenis bubur $\mathbf{n}(\%)$} & \multirow{2}{*}{ Total } \\
\cline { 2 - 3 } & HA & Soya & \\
\hline Naik / Tetap & $6(7,1)$ & $3(3,6)$ & 9 \\
Turun / Tidak timbul & $41(48,8)$ & $34(40,5)$ & 75 \\
\hline Total & 47 & 37 & 84 \\
\hline
\end{tabular}


susu sapi pada akhir penelitian pada kedua kelompok bubur yang hanya menggunakan susu hipoalergenik atau ASI (Tabel 5).

Uji statistik menunjukkan hubungan yang tidak bermakna $(p=0,120)$. Hal ini menunjukkan bahwa bubur protein soya yang dikombinasi dengan susu hipoalergenik atau ASI mempunyai manfaat yang sama dengan bubur hipoalergenik dalam mencegah timbulnya gejala alergi pada bayi dengan bakat atopi. Pada kelompok bubur protein soya, terdapat 6 subyek penelitian yang dilakukan pemeriksaan $\operatorname{IgE}$ soya karena menunjukkan gejala alergi. Hasil pemeriksaan keenam subyek tersebut menunjukkan hasil yang negatif $\mathrm{Hal}$ ini menandakan bahwa kemungkinan gejala alergi tersebut juga tidak disebabkan oleh bubur soya tersebut.

Subyek penelitian pada kelompok bubur HA yang menunjukkan hasil pemeriksaan $\operatorname{IgE}$ spesifik protein susu sapi akhir yang positif ternyata 2 di antaranya mengkonsumsi susu formula bayi biasa. Proses sensitisasi terhadap alergen protein susu sapi pada subyek ini kemungkinan disebabkan oleh protein susu sapi yang terdapat pada susu formula bayi tersebut atau dapat berasal dari formula hipoalergenik yang masih mengandung sebagian kecil molekul protein susu sapi baik pada formula susu hipoalergenik ataupun pada bubur HA. Pada kelompok bubur soya yang me-

Tabel 5. Pemeriksaan IgE spesifik protein susu sapi pada akhir penelitian pada kedua bubur yang hanya menggunakan susu hipoalergenik atau ASI

\begin{tabular}{lccc}
\hline \multirow{2}{*}{ IgE susu sapi } & \multicolumn{2}{c}{ Jenis bubur $\mathbf{n}(\%)$} & \multirow{2}{*}{ Total } \\
\cline { 2 - 3 } & HA & Soya & \\
\hline Negatif & $27(48,2)$ & $16(28,6)$ & 43 \\
Positif & $5(8,9)$ & $8(14,3)$ & 13 \\
Total & 32 & 24 & 56 \\
\hline
\end{tabular}

nunjukkan hasil pemeriksaan $\operatorname{IgE}$ spesifik protein susu sapi akhir yang positif ternyata 3 di antaranya mengkonsumsi susu formula bayi biasa. Proses sensitisasi terhadap alergen protein susu sapi pada subyek ini kemungkinan disebabkan oleh protein susu sapi yang terdapat pada formula susu reguler tersebut atau dapat berasal dari formula susu hipoalergenik yang dikonsumsinya (Tabel 6).

Berdasarkan hasil uji statistik, tidak didapatkan hubungan yang bermakna antara kadar IgE spesifik protein susu sapi pada akhir penelitian dengan evaluasi skor $(\mathrm{p}=0,660)$ (Tabel 6). Hasil kadar IgE spesifik protein susu sapi yang positif tidak selalu menunjukkan adanya gejala alergi.

Pada penelitian juga diamati kenaikan berat badan dan panjang badan bayi setiap bulan dan semua bayi berhasil diikuti perkembangannya sampai akhir penelitian. Didapatkan rerata kenaikan berat badan setiap bulan $(423 \pm 172)$ gram, dengan rentang terbanyak antara (300-500) gram (53,6\%). Pada kelompok bubur HA didapatkan rerata kenaikan berat badan setiap bulan (436 $\pm 149)$ gram, dengan rentang terbanyak antara (300-500) gram $(55,3 \%)$, sedangkan pada kelompok bubur soya didapatkan rerata kenaikan berat badan setiap bulan (407 $\pm 198)$ gram, dengan rentang terbanyak antara (300-400) gram $(32,4 \%)$. Rerata kenaikan panjang badan setiap bulan didapatkan $(1,72 \pm 0,76) \mathrm{cm}$, dengan rentang terbanyak antara $1-2 \mathrm{~cm}(59,5 \%)$. Rentang terbanyak ini tidak berbeda pada kelompok bubur HA dan soya, yaitu masing-masing $63,8 \%$ dan $54,1 \%$ dengan rerata $(1,65 \pm 0,67) \mathrm{cm}$ dan $(1,82 \pm 0,86) \mathrm{cm}$.

Rerata kenaikan berat badan dan panjang badan menunjukkan hasil yang berbeda antara kunjungan pertama, yang dilakukan pada bulan ke-1 (first follow up), dengan kunjungan terakhir, yang dilakukan setelah bulan ke-6 (last follow up). Pada kunjungan pertama didapatkan rerata kenaikan berat badan adalah (527 \pm

Tabel 6. Pemeriksaan IgE spesifik protein susu sapi pada akhir penelitian berdasarkan jenis bubur

\begin{tabular}{llccc}
\hline \multirow{2}{*}{ Jenis bubur } & \multicolumn{2}{c}{ Evaluasi skor (\%) } & \multirow{2}{*}{ Total } \\
\cline { 3 - 4 } & & Naik/ tetap & Turun/ tidak timbul & \\
\hline \multirow{2}{*}{ HA } & IgE susu sapi negatif & $4(11,8)$ & $23(67,6)$ & 27 \\
& IgE susu sapi positif & $0(0)$ & $7(20,6)$ & 7 \\
& Total & 4 & 30 & 34 \\
Soya & IgE susu sapi negatif & $1(3,7)$ & $15(55,6)$ & 16 \\
& IgE susu sapi positif & $1(3,7)$ & $10(37)$ & 11 \\
& Total & 2 & 25 & 27 \\
\hline
\end{tabular}


Sari Pediatri, Vol. 8, No. 4, Maret 2007

271) gram dan rerata kenaikan panjang badan adalah $(2,32 \pm 1,64) \mathrm{cm}$. Angka rerata ini lebih tinggi dibandingkan rerata pada kunjungan terakhir $(423 \pm$ 172) gram untuk berat badan, $(1,72 \pm 0,76) \mathrm{cm}$ untuk tinggi badan. Hal ini sesuai dengan pertambahan berat badan dan panjang badan yang menurun sesuai dengan pertambahan usia pada bayi normal.

Berdasarkan hasil uji statistik, didapatkan tidak ada hubungan yang bermakna antara rerata kenaikan berat badan ataupun panjang badan pada kedua kelompok bubur ( $p=0,261$ dan $p=0,698$ ). Hal ini menandakan bahwa kedua kelompok bubur dapat menghasilkan kenaikan berat badan dan panjang badan yang sama.

Selama penelitian juga dilakukan pencatatan terhadap gejala atau reaksi yang timbul selama pemberian bubur. Reaksi yang terbanyak adalah batuk dan pilek $(22,6 \%)$, diikuti oleh reaksi kulit, seperti gatal $(9,5 \%)$, gangguan gastrointestinal, seperti mual $(7,1 \%)$, kurang menyukai bubur $(4,8 \%)$ dan reaksi pada mata $(1,2 \%)$. Reaksi tersebut tidak selalu timbul dan belum tentu karena pemberian bubur.

\section{Kesimpulan}

Pemberian ASI ekslusif selama 4-6 bulan yang dilanjutkan dengan pemberian bubur protein hidrolisat parsial maupun bubur isolat protein soya dapat mencegah timbulnya alergi pada bayi. Hal ini dibuktikan melalui hasil penelitian bahwa formula bubur protein hidrolisat parsial dan formula bubur isolat protein soya yang dikombinasi dengan ASI atau susu hipoalergenik mempunyai efek yang sama dalam pencegahan alergi susu sapi, baik pencegahan primer maupun sekunder. Sebagian besar bayi mempunyai akseptabilitas atau toleransi yang baik terhadap kedua formula bubur.

\section{Ucapan terima kasih}

Ucapan terima kasih ditujukan kepada PT Sanghiang Perkasa yang telah mensponsori penelitian ini. Ucapan terima kasih juga ditujukan kepada dr. Ratih Dewi Palupi dan dr. Mazdar Helmy yang telah membantu dalam penyelesaian laporan hasil penelitian ini.

\section{Daftar Pustaka}

1. Bock SA. Prospective appraisal of complaints of adverse reactions to foods in children during the first 3 years of life. Pediatrics 1987; 79:683-8.

2. Eggesbo M, Halvorsen R, Tambs K. Prevalence of parentally perceived adverse reaction to food in young children. Pediatr Allergy Immunol 1999; 10:122-32.

3. Schrader JJP, van den Bogart JPH, Forget P. Cow's milk protein intolerance in infants under 1 year of age: a prospective epidemiological study. Eur J Pediatr 1993; 152:640-4.

4. Host A., Halken S. A prospective study of cow's milk alergy in Danish infants during the first 3 years of life. Alergy 1990;45:587-96.

5. H?st A. Halken S. Approach to feeding problems in the infant and young child. Dalam: Leung DYM, Sampson HA, Geha RS, Szefler SJ, penyunting. Pediatric Allergy principles and practice. Missouri, Mosby, 2003. h. 488-94.

6. H?st A. Cow's milk protein alergy and intolerance in infancy. Some clinical, epidemiological and immunological aspects. Pediatr Allergy Immunol 1994; 5:1-36.

7. Molkhou P. Food allergies, present and future problems. Belgium, The UCB Institute of Allergy.2000. h. 46-50.

8. Iacono G, Carrocio A, Montalto G. Severe infantile colic and food intolerance: a long-term prospective study. J Pediatr Gastroenterol Nutr 1991; 12:332-5.

9. Zeiger RS, Sampson HA, Bock SA. Soy allergy in infants and children with IgE-associated cow'smilk allergy. J Pediatr 1999; 134:614-22.

10. Ebisawa M, Sugizaki C, Ikeda Y, Tachimoto H. Development of food allergy during infancy. APAPARI-KAPARD Joint congress. Seoul, Korea. April 2005.

11. Van Bever H. Preventive tretment of childhood asthma. APAPARI-KAPARD Joint Congress. Seoul, Korea. April 2005.

12. Vanto T, Helpplia S, Juntunen-Backman K, Kalimo K, Klemola T, Korpela R. Prediction of the development of tolerance to milk in children with cow's milk hypersensitivity. J Pediatr 2004; 144:218-22. 